\title{
Vestigios de la costumbre local relativa al régimen matrimonial entre los judíos de Castilla (Salamanca, 1500)
}

Marina Girona Berenguer**

ILC, CSIC

ORCID ID: http:// orcid.org/0000-0003-4885-6847

Durante el verano de 1500 se lleva a cabo en Salamanca un interrogatorio en relación al proceso incoado ante la Audiencia Real de Valladolid, que enfrenta a Isabel de Cartagena, conversa, con el convento de Santa María de la Anunciación de la ciudad, al que reclama la entrega de algunos bienes que habían pertenecido a su marido Abrahán de la Fuente. La información ofrecida por los testigos, todos recién convertidos, contiene datos relativos a la costumbre local y a las normas legales judías en relación al régimen matrimonial y a la transmisión de la propiedad conyugal entre los judíos de Castilla en las décadas finales del siglo xv, con especial detenimiento en la situación de Salamanca y Zamora.

Palabras clave: Historia de los judíos; siglo XV; Corona de Castilla; Zamora; costumbre y norma local; matrimonio; dote; herencia; justicia; conversos.

Traces of Local Custom Concerning Matrimonial Property Regime among the Jews of CAStile (Salamanca, 1500). - In the summer of 1500, an interrogation regarding a lawsuit litigated before the Royal Court of Justice of Valladolid between Isabel de Cartagena, a Jewish convert, and the convent of Santa Maria de la Anunciacion, because of the inheritance of Isabel's first husband, Abrahan de la Fuente, was carried out in Salamanca. The information provided by the witnesses, all of them recently converted, contains interesting information concerning local custom (minhag) and Jewish legal communal norms related to marital regime and transmission among Castilian Jews, especially in Salamanca and Zamora, throughout the final decades of the fifteenth century.

KeYwords: History of the Jews; Fifteenth Century; Crown of Castile; Zamora; Minhag; Marriage; Dowry; Inheritance; Justice; Converts.

*Este trabajo ha sido realizado en el marco del proyecto de investigación «Guinzé Sefarad (2013-2015): Edición y estudio de documentos históricos y textos halájicos hebreos y aljamiados», financiado por el MINECO (ref. núm. HAR2012-34338).

***marina.girona@cchs.csic.es

Copyright: () 2018 CSIC. Este es un artículo de acceso abierto distribuido bajo los términos de la licencia de uso y distribución Creative Commons Reconocimiento 4.0 Internacional (CC BY 4.0). 
El 13 de julio de 1500, el converso Fernando de la Peña, procurador de su esposa Isabel de Cartagena en el pleito que esta mantenía con el convento de Santa María de la Anunciación, entregaba al juez local de Salamanca comisionado por los oidores de la Audiencia Real de Valladolid un cuestionario para interrogar a los testigos. El litigio estaba siendo tratado por el tribunal real y tenía su origen en los derechos de la herencia del judío Abrahán de la Fuente, con el que Isabel había estado casada antes de su conversión. El interrogatorio intentaba dilucidar cuestiones relacionadas con la costumbre local relativa al régimen matrimonial vigente entre los judíos de Salamanca con anterioridad a 1492, y para ello, la parte de Isabel había llamado como testigos a varios convertidos, en su mayor parte asentados en Salamanca después de la prohibición del judaísmo en el reino. El objetivo era averiguar si la costumbre local prevalente entre los judíos obligaba a los cónyuges a compartir sus bienes (es decir, en régimen de bienes comunes), o bien si imperaba el régimen privativo.

La información contenida en el interrogatorio mencionado nos da pie para desvelar y analizar las alusiones referentes a algunas costumbres locales relativas al régimen matrimonial y al derecho sucesorio entre los judíos de Salamanca y Zamora a fines del siglo XV. Asimismo, la documentación estudiada nos permite ilustrar el complejo contexto social de la ciudad de Salamanca en torno a 1492.

\section{EL RÉGIMEN MATRIMONIAL Y EL DERECHO SUCESORIO ENTRE LOS JUDÍOS BAJOMEDIEVALES}

El estudio del matrimonio judío en el espacio ibérico medieval entendido como una célula económica (y social) en la que convergen los intereses de las familias de los contrayentes goza de un reciente interés historiográfico'. Los acuerdos inter-familiares establecidos antes de la celebra-

\footnotetext{
${ }^{1}$ Existen estudios relativos a judíos de distintas regiones hispánicas, entre ellos, los de Elka KLEIN, «The Widow's Portion: Law, Custom, and Marital Property among Medieval Catalan Jews», Viator 31 (2000) págs. 147-163, y «Splitting Heirs: Patterns of Inheritance among Barcelona's Jews», Jewish History 16 (2002) págs. 49-71; Juan Jesús VIRTO IBÁNEZ, «"Documentos en transición”: La legalización ante notario de documentos judíos utilizados por conversos en el pleito por la herencia de Beatriz de Arqueñigo», Sefarad 72 (2012) págs. 55-100; y Javier CASTAÑo, «Entangled Dowries of Converts in Early Modern Navarre», en Worlds Apart, Worlds Encounter: Identity, Society, and Culture in the Early
} 
ción de un casamiento y reflejados en el contrato matrimonial, son claves para entender la posición y estructura de la familia judía en el periodo tardo-medieval. La constitución de una nueva unidad familiar iba pareja al aporte de un capital significativo, la dote y las arras, que ponía las bases de desarrollo de la economía familiar. Algunos investigadores han insistido en la necesidad de revalorizar la importancia de dichas contribuciones económicas, en especial de la dote, y las estrategias destinadas a asegurar su preservación ${ }^{2}$. Por otra parte, el régimen matrimonial englobaba otros bienes aparte de la dote y las arras, como los bienes ganados durante el matrimonio, y también regulaba su transmisión.

La institución de un régimen matrimonial, ya sea de bienes comunes o privativos, sujeto siempre a las condiciones acordadas por las familias de los contrayentes y por estos mismos durante el matrimonio, condicionaba el acceso al patrimonio de los cónyuges y determinaba el derecho sucesorio. La preeminencia de un régimen matrimonial específico podía verse condicionada por circunstancias que repercutían en la estabilidad socioeconómica de la familia judía. Este dato se constata tanto entre los judíos del centro de Europa como entre los de algunas regiones mediterráneas en donde se observa cómo las arras aportadas por el novio al matrimonio desaparecen o se limitan como medida de prevención ante la imposibilidad de restituirlas en ese momento ${ }^{3}$.

Modern Period, eds. Avriel Bar-Levav y Claude D. Stuczynski (Jerusalem: The Zalman Shazar Center, 2018 [en prensa]), y «The Orphans' Portion and the Jews of Miranda do Douro in 1490», en Portuguese Jews, New Christians, and 'New Jews.' A Tribute to Roberto Bachmann, eds. Bruno FeItLer y Claude D. StuCZynski (Leiden: Brill, 2018) págs. 102-120, así como las distintas comunicaciones presentadas en la sesión «Ginze Sefarad: Dowries, Jewish Women, and Courts in Late Medieval Iberia», del Seventeenth World Congress of Jewish Studies (Jerusalén, 2017).

${ }^{2}$ Ariel ToAfF, Il vino e la carne. Una comunità ebraica nel Medioevo (Bologna: Il Mulino, 1989) págs. 22-35; Luciano AlLEGra, Identità in bilico. Il ghetto ebraico di Torino nel Settecento (Torino: S. Zamorani, 1996) págs. 165-208, y Michaël GASPERONI, «La misura della dote. Alcune reflesioni sulla storia della famiglia ebraica nello Stato della Chiesa in età moderna», en Vicino al focolare e oltre. Spazi pubblici e privati, fisici e virtuali della donna ebrea in Italia (secc. $X V$-XX) (Firenze: La Giuntina, 2015) págs. 175-216.

Elliott Horowitz, «The Dowering of Brides in the Ghetto of Venice: Between Tradition and Change, Ideas and Reality» [en hebreo], Tarbiz 56 (1987) págs. 347-371: 347-352; Israel Y. YuvAL, «Monetary Arrangements and Marriage in Medieval Ashkenaz» [en hebreo], en Religion and Economy: Connections and Interactions, ed. Menahem BENSAsson (Jerusalem: The Zalman Shazar Center, 1995) págs. 191-207, y Anna Esposito, 
La transmisión de los bienes del matrimonio estaba regulada por el derecho talmúdico que establece que en caso del fallecimiento del marido, la mujer solo debía recuperar la dote que su familia había aportado al matrimonio. En Mišné Torá de Maimónides y en leyes locales posteriores se regulaba el derecho sucesorio sin entrar en particularidades del régimen matrimonial establecido ${ }^{4}$. Así, desde el siglo XIII algunas ordenanzas locales promulgadas por los judíos de Castilla estipulaban que la mujer tenía derecho a recibir el total del contrato matrimonial (dote y arras) o al menos parte de las arras, dependiendo de si había, o no, descendientes. Publicaciones de distinta factura han estudiado el contenido de varias tacanot ${ }^{5}$. Sin embargo, la historiografía actual carece de un estudio comparativo que evidencie la evolución de la norma a través de los siglos bajomedievales en su contexto hispánico. Con todo esto, el panorama quedaría incompleto si no se incorporara al estudio el análisis de la de documentación procesal y notarial.

A través del examen de los procesos litigados ante la Audiencia Real de Valladolid a fines del siglo XV, investigaciones recientes atestiguan un alto número de pleitos litigados en relación a la dote y arras y la herencia entre judíos, como también entre cristianos ${ }^{6}$. En consecuencia, estos

«Desigualdades económicas y ciudadanía: El problema de la dote», Anales de historia antigua, medieval y moderna 49 (2015) págs. 39-48.

${ }^{4}$ Maimónides, Hilkot Išut, Séfer Našim, caps. 16-20; $c f$. Olga Ruiz Morell y Aurora Salvatierra Ossorio, Leyes sobre el matrimonio (Hilkot Ishut) del Mishné Torá (Estella: Editorial Verbo Divino, 2010) págs. 193-246.

${ }^{5}$ José Llamas, «Documentos para la historia jurídica de las aljamas hebreas de Toledo y Molina», Religión y cultura XIX (1932) págs. 263-276; Abraham I. Laredo, «Las taqanot de los expulsados de Castilla en Marruecos y su régimen matrimonial y sucesorial», Sefarad 8 (1948) págs. 245-276; Shalom BAR-AsHer, The Taqanot of the Jews of Morocco: A Collection of Communal Ordinances from the 16th to 18 th Century as found in Kerem Hemer II by Avraham Ankawa [en hebreo] (Jerusalem: The Zalman Shazar Center, 1977); Shraga Abramson, «On the Takkanah of Tuletula (Toledo) regarding the Husband's Inheritance of his Wife's Estate» [en hebreo], Zion 60 (1995) págs. 201-224; Aharon Shweka, «The Controversy about the Marriage Statute (Taqqanat ha-Nissu'in) of Toledo» [en hebreo], Tarbiz 68 (1998) págs. 87-127, y Yolanda Moreno Koch, «La mujer sefardí en Marruecos después de la expulsión de 1492», en Movimientos migratorios y expulsiones en la diáspora occidental. Terceros encuentros judaicos de Tudela (14-17 de julio de 1998) (Pamplona: Universidad Pública de Navarra, 2000) págs. 101-107.

${ }^{6}$ Elisa CASELLI, Antijudaïsme, pouvoir politique et administration de la justice. Juifs, 
textos no solo revelan la importancia y necesidad del establecimiento de una normativa en materia matrimonial y sucesoria, sino también plantean problemáticas judiciales, que nos dan a conocer algunos datos acerca de los usos y costumbres de los matrimonios judíos en ese periodo.

Asimismo, la documentación generada a partir de 1492 en relación a judíos convertidos ha de ser incorporada al estudio del régimen matrimonial, y debe ser puesta en contexto a través de un análisis conjunto con las fuentes previas. El estudio de este tipo de documentos nos permite completar historias truncadas (en apariencia) de judíos y sus familias antes y tras la prohibición del judaísmo, e incluso nos adentra en novedosas cuestiones y problemáticas de amplio espectro.

Un estudio sistemático de la documentación contenida en el Registro General del Sello de Corte y el Registro de Ejecutorias de la Real Chancillería de Valladolid constata la existencia de demandas y pleitos iniciados por conversos después de 1492 en los que alegan derechos de sucesión basados en la ley judía para recuperar la dote y arras. Casos como el de la viuda Beatriz González, vecina de Ágreda, que en 1494 solicitaba la intervención de la justicia real con el fin de que su otrora suegro le restituyese su dote y arras ${ }^{7}$, o el de Mencía Velázquez, que reclamaba que la ejecución ordenada por las autoridades de Arévalo contra su marido se había realizado en bienes correspondientes a los de su contrato matrimonial (judío) $)^{8}$, son comunes en la documentación y nos permiten precisar los problemas que los ocasionan. Sin embargo, en ninguno de estos litigios se trata la cuestión del régimen matrimonial judío y las distintas posibilidades de transmisión de la herencia desde una perspectiva teórico-legal, que es lo que singulariza el caso que aquí presentamos.

chrétiens et convertis dans l'espace juridictionnel de la Chancillería de Valladolid ( $X V^{e}$ XVI $I^{e}$ siècles) (Lille: Atelier national de reproduction des thèses, 2014) pág. 20, y Roberto González Zalacaín, La familia en Castilla en la Baja Edad Media: violencia y conflicto (Madrid: Congreso de los Diputados, 2014) págs. 194-222 y 235-252.

${ }^{7}$ Archivo General de Simancas, Registro General del Sello [en adelante, AGS, RGS], 11-III-1494, fol. 324 (Medina del Campo); $c f$. Enrique Cantera Montenegro, «Notas acerca de la expulsión de los judíos en la diócesis de Osma (Soria)», Espacio, tiempo y forma. Serie III. Historia Medieval 13 (2000) págs. 57-84: 76-77.

${ }^{8}$ Archivo de la Real Chancillería de Valladolid [en adelante, ARChV], Pleitos Civiles, Quevedo (Fenecidos), caj. 1412, 4 (9-I-1514); cf. M. ${ }^{a}$ Fuencisla García CASAR, «Pleito de unos judeoconversos de Arévalo», El Olivo 13 (1989) págs. 91-103, y CASELLI, Antijudaïsme, pouvoir politique et administration de la justice, págs. 339-351. 


\section{Los bienes de los CONVERTidos y Retornados a Salamanca DESPUÉS DE 1492}

Una de las consecuencias inmediatas del retorno de judíos a Castilla una vez convertidos es el intento de recuperar desde finales de 1492 los bienes muebles e inmuebles que habían dejado en sus lugares de origen. Los judíos que solicitaron licencia para volver al reino tras su conversión estaban amparados por una disposición otorgada por los Reyes Católicos que les aseguraba la recuperación de las propiedades que hubiesen vendido en condiciones desventajosas o de las deudas que hubieran quedado sin cobrar'. Sin embargo, el proceso de recuperación no era automático ni sencillo y la documentación de la época constata la existencia de pleitos emprendidos ante la justicia real por los neófitos ante la negativa de los nuevos propietarios y de las autoridades locales de posibilitar la devolución de los bienes ${ }^{10}$.

Hasta 1492, la judería de Salamanca se había ubicado en la zona suroeste de la ciudad bajo la influencia del bando de San Benito, liderado por el linaje de los Maldonado. La extensión de la judería se prolongaba desde la calle Traviesa hasta la puerta de San Lorenzo, en la colación de San Juan, donde se encontraba el alcázar hasta su destrucción en 1472. La documentación histórica disponible proporciona información sobre los traspasos y arrendamientos de viviendas que los judíos tenían a censo del cabildo catedralicio y de diferentes monasterios de la ciudad, como los de San Esteban y San Agustín, en el último tercio del siglo XV. Asimismo, las fuentes nos informan acerca de personalidades judías de la ciudad como fue R. Ya'acob b. Habib, maestro de la Ley, más conocido por su actividad intelectual después de 1492 en la diáspora mediterránea ${ }^{11}$.

\footnotetext{
${ }^{9}$ Yolanda Moreno Koch, «De la diáspora hacia Sefarad: ¿La primera carta de regreso de un judío convertido?», Michael 11 (1989) págs. 257-265, nota 26.

${ }^{10}$ M. Antonia VArona García, «Pleitos de judíos en la Real Chancillería de Valladolid: regesta de sus cartas ejecutorias (1486-1495)», Sefarad 54 (1994) págs. 155-193: 189-193, y Elisa CASELLI, «Del exilio al terruño. Las reclamaciones ante la justicia de los judíos que regresaron bautizados (1492-1525)», Chronica Nova 37 (2011) págs. 143-174.

${ }^{11}$ Joseph HACKER, «R. Jacob b. Solomon Ibn Habib. An Analysis of Leadership in the Jewish Community of Salonika in the XVI ${ }^{\text {th }}$ Century» [en hebreo], en Proceedings of the Sixth World Congress of Jewish Studies (Jerusalem: World Union of Jewish Studies, 1976) vol. II, págs. 117-126. Una fuente hebrea coetánea lo sitúa en la ciudad como continuador de R. Isaac de León al frente de una escuela rabínica; $c f$. David FränKEL (ed.), Zera' anašim (Husyatin: Hebrat Dobebé Šifté Yešenim, 1902) pág. 72, mencionado en
} 
Tras hacerse efectivo el decreto de expulsión, los judíos que decidieron regresar al reino previa conversión no tenían garantizada la restitución de sus posesiones ni siquiera bajo el amparo de las cartas de seguro concedidas por los reyes. En el trascurso de los meses que sucedieron a agosto de 1492, algunos particulares avecindados en Salamanca, al igual que ocurrió en otras ciudades, obtuvieron el traspaso de viviendas y otras propiedades de judíos, situadas en la judería. De igual modo, los monasterios y conventos de la ciudad también se vieron favorecidos por las mercedes que les otorgaban el derecho sobre dichos bienes y también sobre los que habían sido requisados a individuos considerados herejes ${ }^{12}$.

Asimismo, los Reyes Católicos comisionaron a varios jueces para que hicieran una pesquisa general que les permitiera identificar a los judíos que habían sacado del reino bienes de manera ilícita y averiguar su cuantía y ubicación con el fin de proceder a su embargo. En el obispado de Salamanca, este registro fue llevado a cabo entre 1494 y 1496 por Fernando Pérez de Meneses, cuyas notas arrojan luz sobre el paradero de algunos judíos de Salamanca después de $1492^{13}$.

La intervención de los linajes salmantinos en el destino de los bienes de los judíos es una cuestión pendiente de estudio. En esta ocasión podemos adelantar que Alonso de Fonseca y Acevedo, arzobispo de Santiago (hasta 1501), presidente de la Audiencia Real de Valladolid (hasta 1492) y miembro de los linajes Maldonado y Acevedo, se vio involucrado en, al menos, un litigio contra un neófito que había regresado a la ciudad ${ }^{14}$. En 1498 el arzobis-

Javier CASTAÑo, «"Flüchtige Schimären der Convivencia": Die Juden in Kastilien und ihre Eliten (1418-1454)», en Integration - Segregation - Vertreibung. Religiöse Minderheiten und Randgruppen, eds. Klaus Herbers y Nikolas JASPERT (Münster - Berlin: LIT-Verlag, 2011) págs. 179-212: 205. Podemos identificarlo con su homónimo R. Jacob Abén Habib que en 1486 actuaba en Ciudad Rodrigo como tutor de su sobrino Salamón, hijo de Hayn Abén Habib, en un pleito que sostenían contra los herederos de Françisco de Silva (AGS, RGS, 28-VII-1486, fol. 45 (Valladolid); apud Carlos CARrete Parrondo, Fontes Iudaeorum Regni Castellae, vol. I. Provincia de Salamanca [en adelante, FIRC, I] (Salamanca: Universidad Pontificia de Salamanca, 1981) págs. 64-65 (doc. 110).

${ }^{12}$ FIRC, I, pág. 136 (doc. 394).

${ }^{13}$ Miguel Ángel Ladero QueSADA, «Bienes y deudas dejados sin cobrar por los judíos leoneses en 1492», en Escritos dedicados a José María Fernández Catón, eds. Manuel C. Díaz y Díaz et al. (León: Centro de Estudios e Investigación San Isidoro, 2004) vol. I, págs. 717-741: 719.

${ }^{14}$ AGS, RGS, 11-VII-1498, fol. 113 (Zaragoza). 
po había alegado ante los jueces de la Corte que el judío Yuçé de la Fuente, ahora llamado Pedro Fernández de la Peña, le había dejado a deber una deuda al mayordomo de aquel antes de su salida del reino. Por este motivo, solicitaba que le hiciera entrega de las casas que el judío había poseído con el fin de suplir la cantidad debida. Ya con anterioridad a 1495 el arzobispo había echado a la mujer de Alonso de Oviedo, vecino de la ciudad, de las casas propiedad de Yuçé, información contenida en el registro de Pérez de Meneses ${ }^{15}$. Sin embargo, este hecho era omitido por Alonso de Fonseca en su alegación.

La influencia y poder del arzobispo en Salamanca también es relevante en el caso que analizamos. Desde la década de 1480, Alonso de Fonseca había promocionado uno de los conventos de la ciudad, el de Santa María de la Anunciación (antes Santa Úrsula), que había sido fundado en la década de 1470 por la familia Maldonado ${ }^{16}$. La importancia de este dato está relacionada con el interrogatorio que estudiamos, puesto que en una fecha indeterminada posterior al verano de 1492 el monasterio de Santa María de la Anunciación había recibido o adquirido algunos bienes de la herencia de un judío llamado Abrahán de la Fuente.

Sin embargo, la estrecha vinculación entre el monasterio, la familia Maldonado y el arzobispo de Santiago no fue óbice para que la que había sido mujer de Abrahán, una neófita que por entonces se hacía llamar Isabel de Cartagena, decidiera reclamar como heredera legítima ciertos bienes de su difunto marido.

3. UN CUESTIONARIO SOBRE EL RÉGIMEN MATRIMONIAL DE LOS JUDÍOS: SALAMANCA Y ZAMORA

El litigio entre Isabel de Cartagena y el convento de Santa María de la Anunciación «sobre razón de çiertos bienes y herencias» había dado comienzo en una fecha incierta anterior al mes de julio de $1500^{17}$. Así lo

\footnotetext{
${ }^{15}$ LADERo QuesadA, «Bienes y deudas dejados sin cobrar por los judíos leoneses en 1492», pág. 731.

${ }^{16}$ José María Martínez Frías, «La fundación del convento de Santa Úrsula de Salamanca y su posible relación posterior con el foco hispano-flamenco toledano», Boletín del Seminario de Estudios de Arte y Arqueología 67 (2001) págs. 157-187: 158-167.

${ }^{17}$ La parte que se conserva del proceso (10-28 de julio de 1500) incluye el texto de uno de los interrogatorios, en ARChV, Pleitos Civiles, Zarandona y Walls, caja 1365-2;
} 
señala una carta de receptoría de testigos promulgada el 1 de julio ${ }^{18}$, que indica que los jueces de la Audiencia Real, en donde se estaba desarrollando el pleito, habían dictado una sentencia provisional por la que instaban a Isabel y al convento a proseguirlo en grado de apelación.

La carta de receptoría era presentada el 10 de julio por Fernando de la Peña, procurador y marido de Isabel, ante el bachiller y alcalde de Salamanca, Rodrigo Guillén, para que «tomase e resçibiese juramento e sus dichos e disposyçiones de los testigos que ante él presentase». El lunes 13 de julio, Fernando entregaba al juez local un cuestionario compuesto por tres preguntas: a) Si los testigos habían conocido a Abrahán de la Fuente y a Azibuena, su tercera mujer, y si conocían a Isabel de Cartagena; b) Cuál había sido la «costumbre» entre los judíos de Salamanca cuando casaban por segunda (o tercera) vez en relación a los bienes que traían el novio y la novia al matrimonio; y c) Si conocían a varios de los testigos presentados (que ya habían testificado con anterioridad), que no eran naturales de Salamanca, y cuáles eran las costumbres sobre el régimen matrimonial de bienes comunes entre los judíos de otros lugares.

El asunto planteado en el interrogatorio se centra en la costumbre general establecida por los judíos de Salamanca en torno al régimen matrimonial. A diferencia de los procesos por herencia seguidos antes de 1492, en este momento los tribunales ya no podían recurrir a judíos expertos en cuestiones halájicas, aunque disponían de los testimonios de conversos familiarizados en distinto grado con la ley judía, como ocurre en este caso.

\subsection{La familia judía De la Fuente (luego, De la Peña): 1480-1501}

Durante las dos últimas décadas del siglo XV el patronímico De la Fuente se repite entre judíos vecinos de Salamanca ${ }^{19}$, y cabe la posibilidad

cf. FIRC, I, págs. 140-141 (doc. 409), que da una signatura errónea.

${ }^{18}$ AGS, RGS, 1-VII-1500, fol. 48 (Valladolid).

${ }^{19}$ La mención más temprana encontrada de un judío con ese patronímico es la de Symuel de la Fuente, procurador de la aljama de los judíos de Salamanca ante el concejo en 1480, AGS, RGS, 3-IX-1480, fol. 214 (Medina del Campo); apud Luis SuÁrez FERNÁNDEZ, Documentos acerca de la expulsión de los judios (Valladolid: CSIC, 1964) págs. 189-191 (doc. 55). Un año después, se registra la mención al «judío de la Fuente», que tenía a censo del monasterio de San Agustín unas casas en la calle Mayor de la judería, 
de que hiciera alusión a un topónimo de procedencia, como es la villa de Fuentesaúco, localidad situada al noroeste de Salamanca ${ }^{20}$.

Uno de los miembros de esta familia era Abrahán de la Fuente, que se había casado en segundas nupcias con Isabel de Cartagena, entonces judía, y se volvió a desposar por tercera vez con la judía Azibuena. No sabemos con certeza si el matrimonio entre Abrahán e Isabel se disolvió antes de que este contrajera su tercer matrimonio. Sin embargo, no resulta fácil de explicar que una mujer divorciada (en este supuesto caso, Isabel) reclamara años más tarde la herencia de su ex-marido si ya se había disuelto la unión.

Tras el fallecimiento de Abrahán, que se produjo antes de la expulsión, el vínculo entre Isabel y la familia De la Fuente se mantuvo al contraer esta un nuevo matrimonio con Fernando de la Peña, sobrino de Abrahán e hijo de doña Oro Buena. ¿Qué motivo propició el enlace entre Isabel y Fernando?, ¿Es posible que su casamiento estuviera relacionado con una práctica de tipo levirático debido a la ausencia de hijos del matrimonio de Abrahán e Isabel?, ¿O se trata más bien de una estrategia para conservar los bienes conyugales?

Fernando y su hermano Ysaque de la Fuente (luego, Beltrán de la Peña) también vivían en Salamanca, aunque poseían otros inmuebles en las localidades próximas de Peñaranda de Bracamonte y Santiago de la Puebla, ambas bajo jurisdicción señorial ${ }^{21}$. En 1492 tras hacerse efectivo el decreto de expulsión, algunos miembros de la familia De la Fuente optaron por mantenerse fieles a su fe y abandonar Castilla, y lo lógico

Archivo Histórico Nacional [en adelante, AHN], Clero, lib. 10620, núm. 10 (3-III-1481) y 11 (7-III-1481); $c f$. FIRC, I, págs. 123-124 (docs. 346-347). Se trataba de Mosé de la Fuente, que en 1490 poseía las mismas casas a censo perpetuo; AHN, Clero, lib. 10620, doc. 2 (10-V-1490); $c f$. FIRC, I, págs. 130-131 (doc. 373). En esa misma década vive en la ciudad Hayn de la Fuente, casado con doña Çinhá, que en 1484 había traspasado a Alfonso de Peñaranda una casa sita en la judería; Archivo Catedralicio de Salamanca, caj. 45, leg. 1, núm. 37; cf. Florencio Marcos RodríGuez, Catálogo de documentos del archivo catedralicio de Salamanca (siglos XII-XV) (Salamanca: Universidad Pontificia de Salamanca, 1962) pág. 195 (doc. 1062), y FIRC, I, pág. 124 (doc. 350).

${ }^{20}$ En 1487, Yuçé de la Fuente, judío de Fuentesaúco, se avecindaba en Santiago de la Puebla (Salamanca) con motivo de un arrendamiento de rentas; AGS, RGS, 22-III-1487, fol. 61 (Tordesillas); $c f$. FIRC, I, págs. 143-144 (doc. 420).

${ }^{21}$ LADERO QUESADA, «Bienes y deudas dejados sin cobrar por los judíos leoneses en 1492», págs. 730 y 734 . 
es pensar que hubieran pasado al reino vecino de Portugal. Sin embargo, hubo algunos que retornaron tras su bautismo, como ocurrió con los hermanos Fernando y Beltrán (antes Ysaque), que sustituyeron el patronímico De la Fuente por De la Peña ${ }^{22}$. Ambos hermanos optaron por regresar entre 1493 y 1495 a su ciudad de origen, y es entonces cuando Fernando e Isabel de Cartagena se unieron en matrimonio eclesiástico (lo que no excluye que ya se hubieran casado siendo judíos).

La información del casamiento de Fernando de la Peña e Isabel de Cartagena, que fuera mujer de su tío, nos sitúa ante un patrón familiar extenso, en el que las relaciones de sus miembros trascendían del núcleo familiar (padre e hijos) y se veían condicionadas por el devenir de la vida conyugal de sus miembros. Asimismo, cabe destacar la importancia del mantenimiento de la alianza familiar después de la conversión. Como consecuencia de esto último sabemos que un lustro más tarde el matrimonio se vería obligado a solicitar una dispensa canónica que ratificara su compromiso a causa del parentesco existente previamente entre ellos (impedimento por afinidad) ${ }^{23}$.

\subsection{Los testigos del interrogatorio}

La llegada de conversos a Salamanca desde Portugal a través de Ciudad Rodrigo se justifica por la cercanía a la frontera y el atractivo socioeconómico de la ciudad como centro universitario. Quizá sean estos factores los que explican el asentamiento en Salamanca, primero de judíos y luego de conversos y sus familias procedentes de otras regiones del reino, aunque los motivos concretos no son fáciles de explicar. En palabras de un historiador reciente, «las experiencias vividas fueron extraordinariamente diversas, y resulta de todo punto imposible reducirlas todas ellas a un patrón común ${ }^{24} »$.

\footnotetext{
${ }^{22}$ LADERO QUESADA, «Bienes y deudas dejados sin cobrar por los judíos leoneses en 1492», págs. 729-730.

${ }^{23}$ AGS, RGS, 23-X-1500, fol. 77 (Valladolid).

${ }^{24}$ Máximo Diago Hernando, «El ascenso de los judeoconversos al amparo de la alta nobleza en Castilla después de 1492: el caso de Almazán», Sefarad 74 (2014) págs. 145184: 146.
} 
No siempre es posible averiguar las identidades judías previas de los neófitos que se asientan en la ciudad. En el breve lapso de tiempo transcurrido entre la salida de Castilla, la conversión y el regreso, aquellos asumen que, en el plano personal, «el tiempo de los judíos» formaba parte de un pasado intencionadamente difuso. Por esto, no es de extrañar que el interrogatorio no contenga ningún dato alusivo a la conversión de Isabel de Cartagena o de Fernando de la Peña, ni a su vida con anterioridad a 1492 .

Desconocemos el vínculo que unía a los testigos del interrogatorio con la parte de Isabel de Cartagena. Todos ellos la conocían, pero solo los salmantinos (Gabriel de Huerta y Álvaro Gómez) eran los que habían tenido trato con su marido Abrahán de la Fuente, lo que corrobora que la mayoría no había vivido en Salamanca antes de 1492. Por el contrario, procedían de lugares como Zamora (Juan de Çamora, el Viejo, y Pedro de Çamora), Sahagún (Françisco de León), Almazán ${ }^{25}$ (Françisco Palomeque) y Piedrahita (Françisco de Piedrahita), y habían llegado a Salamanca después de la expulsión, a excepción del último que ya se encontraba en la ciudad tres años antes. Es llamativo que el número de testigos foráneos supere al de los oriundos, si tenemos en cuenta que la cuestión a tratar estaba relacionada fundamentalmente con la costumbre legal habituada por los judíos de Salamanca.

En cuanto al perfil socio-profesional de los testigos, es común el oficio de sastre, y en el caso de Álvaro Gómez se nos informa que era casamentero. Por último, no es menos importante la edad, que permite deducir en qué circunstancias personales estaban cuando recibieron el bautismo: Juan y Pedro de Çamora y Álvaro Gómez pasaban de los 55 años, Gabriel de Huerta y Françisco Palomeque rondaban la treintena, mientras que Françisco de Piedrahita era aún joven. Pese a que la mayoría había alcanzado o superado la veintena en 1492, durante el interrogatorio ninguno de ellos hizo mención a su propia experiencia en el terreno matrimonial. Solamente Pedro de Çamora había explicado que su madre, una judía originaria de Benavente, se había trasladado a Zamora después de contraer matrimonio (década de 1440).

\footnotetext{
${ }^{25}$ Sobre los judíos de Almazán antes y después de 1492, véase Carlos Carrete Parrondo y Carolina Fraile Conde, Fontes Iudaeorum Regni Castellae. IV. Los judeoconversos de Almazán, 1501-1505: origen familiar de los Lainez. (Salamanca: Universidad Pontificia de Salamanca, 1987).
} 
4. REgÍMENES MATRIMONIALES, TRANSMISIÓN ENTRE CÓNYUGES Y COSTUMBRE LOCAL: UNA MIRADA RETROSPECTIVA

El contrato matrimonial puede definirse como «un auténtico pacto de familias, que persigue asegurar la permanencia del naciente núcleo doméstico, ayudando a constituir un fondo patrimonial destinado a proveer el sostenimiento de sus integrantes y sujeto a una serie de reglas, un régimen económico, que, en concordancia siempre con el sistema sucesorio vigente, busca posibilitar el adecuado cumplimiento de las transcendentales misiones que tiene encomendadas ${ }^{26} \gg$. De ahí el interés que muestran por los asuntos familiares algunas ordenanzas comunales o tacanot promulgadas por las aljamas de judíos, regulando la práctica matrimonial en cuanto al establecimiento y distinción de los derechos y deberes de los contrayentes y sus familias.

La cuestión principal que se plantea en el interrogatorio es si «quando alguno se casaua con segunda o terçera muger, que todos los bienes heran comunes que cada vno dellos trayan al tienpo que se casauan», es decir, si el régimen matrimonial por el que se regían los judíos en Salamanca era, o no, el de bienes comunes. Junto a la pregunta se añadía la siguiente aclaración, «qu'esta costunbre non se vsaría, nin guardaría en todos los logares, especialmente non se vsaua, nin guardaua en la çibdad de Salamanca», que los testigos debían confirmar.

Con anterioridad a 1492, la jurisdicción sobre cuestiones relacionadas con el matrimonio judío en Castilla recaía en los jueces judíos del lugar y/o en el juez mayor de las aljamas, aunque también se podía apelar a los órganos judiciales del reino. Si bien los expertos basaban sus dictámenes en el Código de Maimónides, que era considerado el principal corpus legal en materia de matrimonio y herencia, los problemas y cuestiones que ocasionaban los mismos debían ser resueltos de acuerdo con una prelación de derechos. En primer lugar se debía recurrir a los pactos matrimoniales acordados por las familias de los contrayentes antes de oficializar la unión del matrimonio. Estas cláusulas se habían puesto por

\footnotetext{
${ }^{26}$ Manuel Ángel Bermejo CAStRiLlo, «Transferencias patrimoniales entre los cónyuges por razón del matrimonio en el derecho medieval castellano», en La familia en la Edad Media: XI Semana de Estudios Medievales (Nájera, del 31 de julio al 4 de agosto de 2000), coord. José Ignacio DE LA IGLESIA DuARTE (Nájera: Instituto de Estudios Riojanos, Gobierno de La Rioja, 2001) págs. 93-150: 94-95.
} 
escrito en el contrato matrimonial, pero también podían constar en otros documentos $^{27}$. Si no se habían establecido condiciones que regulasen el matrimonio, la problemática se debía resolver por medio de las ordenanzas o tacanot promulgadas por la comunidad, que estuvieran en vigencia. Ante la ausencia de una normativa aplicable y en última instancia, se podía hacer uso de la costumbre local entre los judíos, reflejo de las ordenanzas locales y del derecho común. Pese a la existencia de este orden de prelación, en el interrogatorio del pleito la parte de Isabel de Cartagena pregunta por la costumbre local obviando los pactos y las ordenanzas. No obstante, es posible que el recurso a la costumbre fuera consecuencia de la ausencia de ordenanzas vigentes en Salamanca en los años inmediatos a la expulsión.

Asimismo, las autoridades reales también aplicaban una lógica judicial que les permitiese conocer el lenguaje y mecanismos de la sociedad judía, y así resolver los casos de acuerdo con la ley judía. Es por esto que en el litigio que analizamos se requiera la comparecencia de testigos neófitos que arrojen luz acerca del régimen matrimonial vigente en Salamanca a fines del siglo XV.

\subsection{Bienes, régimen matrimonial y transmisión}

Adentrándonos en la esfera de los judíos, el conjunto de bienes aportados al matrimonio por parte de las familias de los contrayentes se denominaba dote (nedunyá) y arras (móhar y toséfet), e incluso cabía la posibilidad de que el novio realizara otras donaciones conocidas como matanot. Todos estos bienes constaban expresamente en la ketubbá o contrato matrimonial y en documentos adicionales con los que se pretendían proteger los intereses económicos de las familias de los contrayentes, y en especial de la novia ${ }^{28}$.

\footnotetext{
${ }^{27}$ José Luis Lacave, Los judíos del Reino de Navarra. Documentos hebreos 1297-1486 (= Navarra judaica VII [Pamplona: Gobierno de Navarra, 1998]) págs. 449-450 (doc. 58).

${ }^{28}$ Así se recoge en una ordenanza de 1496 promulgada por los judíos de Castilla refugiados en Fez: «E por quanto muchas personas de los quehilot, guárdeles su Roca y su Redentor, con las grandes tragedias pasadas e andan ambulantes y fugitivos, están con sus mujeres sin tener documentos de ketubbot y está prohibido para el hombre permanecer con su mujer sin ketubbá» (núm. 1); $f$. LAREDO, «Las taqanot de los expulsados de Castilla
} 
Para ello, solía negociarse previamente un acuerdo prematrimonial por el que las familias judías recurrían a casamenteros y a árbitros que actuaban como intermediarios para establecer las cantidades de bienes y dinero con las que contribuía cada una de las partes, el plazo de entrega y las condiciones matrimoniales ${ }^{29}$. Los bienes aportados por los cónyuges al contrato matrimonial eran inalienables (nikssé șon barzel ${ }^{30}$ ), es decir su valor no podía disminuir, por lo que, en teoría, no se podían vender, ni empeñar.

Una vez formalizado el casamiento, el marido se convertía en gestor de los bienes (dotales) propiedad de la mujer. Aunque podía obtener su usufructo, en caso de que generase pérdidas estaba obligado a restituirlas de sus propios bienes, ya que legalmente no le pertenecían. Lo mismo ocurría con las arras y las donaciones hechas por el novio al matrimonio: estos bienes quedaban «hipotecados» a la mujer, aunque esta no podría hacer uso de los mismos hasta la disolución del matrimonio. Con las ganancias derivadas de los bienes inalienables, la pareja podía y debía invertir en otros bienes y propiedades que acrecentaran el capital inicial. Este segundo tipo de propiedades formaría parte de la comunidad de bienes del matrimonio, lo que se conoce como bienes gananciales.

En relación al régimen privativo, el derecho judío establece que la mujer tenía autonomía respecto a la gestión de los bienes parafernales (nikssé șon melog), esto es los bienes que la mujer había recibido de familiares por medio de donaciones, pero que no formaban parte de la dote. Se trataba de bienes usufructuarios que podían ser vendidos, amortizados y donados por parte de la mujer antes del casamiento y durante el matrimonio. A diferencia de lo establecido respecto a los bienes inalienables, el marido no tenía derecho alguno sobre ellos, ni tampoco era responsable de los mismos, por lo que si su cantidad disminuía, no estaba obligado a restituirla. Solo en caso de que el matrimonio optara

en Marruecos y su régimen matrimonial y sucesorial», pág. 275. Las referencias textuales a las ordenanzas de Fez de 1494 y 1496 están tomadas de la edición y estudio que estoy preparando; presento en cursiva el texto traducido del hebreo.

${ }^{29}$ Tales disposiciones se podían ratificar posteriormente a través de la fe pública notarial.

${ }^{30}$ Respecto a los bienes inalienables (nikssé șon barzel) y parafernales (nikssé șon melog), véase Menahem Elon, «Dowry», Encyclopaedia Judaica, vol. V (2 $2^{\text {a }}$ ed., New York, 2007) págs. 768-772: 769-770. 
por un régimen de bienes comunes, en el que los esposos disfrutaran en conjunto de la totalidad de su patrimonio, el marido podría recibir su usufructo.

El régimen de bienes comunes estaba sujeto a modificaciones y complementos por medio de las ordenanzas comunales, así como por las cláusulas específicas que los contrayentes dispusieran en el contrato matrimonial o en los acuerdos realizados previamente. La normativa relativa a los bienes conyugales variaba según las costumbres imperantes en cada aljama, y queda reflejada en un proceso de regionalización del que quedan evidencias en las ketubbot, como demostró José Luis Lacave ${ }^{31}$. La variedad de costumbres y, en consecuencia, de normas locales era un hecho asumido por los judíos ${ }^{32}$ :

En algunos logares auían sus costunbres segund las condiçiones que ponían al tienpo que se casaua el hombre con la muger, avnque fuesen él biudo o ella, e touiese el vno fijos o el otro fijos, pero qu'el derecho e la ley establesçida entr'ellos hera en el tienpo de los judíos ${ }^{33}$.

Evidentemente las consultas enviadas a las autoridades rabínicas sobre aspectos diversos relativos al matrimonio (y a la herencia) era un fenómeno recurrente, y los judíos de Salamanca no eran ajenos a ello. De hecho, entre las varias consultas realizadas un siglo atrás desde la ciudad a R. Isaac Perfet, una está relacionada con la obligatoriedad de celebrar la boda (nissuín) ante un quórum (minyán) de diez varones adultos ${ }^{34}$. Dicha disposición de tradición talmúdica ${ }^{35}$ trataba de prevenir engaños y casa-

\footnotetext{
${ }^{31}$ José Luis Lacave, Medieval Ketubot from Sefarad [= Hispania Judaica, XI] (Jerusalem: The Hebrew University - Magnes Press, 2002).

${ }^{32}$ Un texto de Fez (1494) señala que «[...] Que ninguno non pueda casar a otro minhag ['costumbre, norma'] que salvo a este minhag por nos ordenado en Fez. E si inovasión quisieren fazer entre ellos, dize en la ketubbá cómo instituyeron y estipularon ser entre ellos el novio y la novia. El qual tenay ['condición'] que estipularon entre ellos sean obligados de lo escribir en la nedunyá, donde non quede sometido a esta nuestra tacaná» (núm. 13); cf. LAREDO, «Las taqanot de los expulsados de Castilla en Marruecos y su régimen matrimonial y sucesorial», pág. 274.

${ }^{33}$ Vid. Apéndice, infra.

${ }^{34}$ Responsum núm. 232; cf. Abraham M. Hershman, Rabbi Isaac Ben Sheshet Perfet and His Times (New York: The Jewish Theological Seminary of America, 1943) pág. 128.

${ }^{35}$ bKetubbot, 8a-b.
} 
mientos forzados y aparece recogida más tarde en las tacanot de Valladolid de $1432^{36}$.

Por otro lado, en el interrogatorio se trataba de dilucidar si entre los judíos de Salamanca prevalecía el régimen matrimonial de bienes comunes sobre el privativo, aun en el caso de segundos y terceros matrimonios, aludiendo al caso de Abrahán de la Fuente. Este aspecto era fundamental para determinar el sistema de transmisión. La única información disponible que nos permite ahondar en ello se contiene en las declaraciones de los testigos que no solo aportan un mejor entendimiento al respecto, sino que constatan también que la costumbre sobre el régimen matrimonial variaba según la localidad. Paradójicamente, pese a la movilidad de los testigos, estos manifestaron su desconocimiento respecto a los usos imperantes en otras comunidades diferentes a las suyas propias.

En sus respuestas al interrogatorio los testigos mostraron distinto grado de pericia, producto bien de su formación o bien de su experiencia personal. En el caso de Juan de Çamora, el Viejo, nos encontramos ante un perito en asuntos legales, pues en su declaración utiliza terminología legal, técnica y objetiva similar a la que aparece en textos legales judíos. Desconocemos su identidad judía previa, pero es significativa la coincidencia onomástica con la del padre del hebraísta Alonso de Zamora, que comienza a trabajar pocos años después en el Estudio salmantino. De hecho, en los apuntes biográficos contenidos en sus Introductiones Artis Grammaticae Hebraicae, Alonso de Zamora escribía que su padre, Juan de Zamora, apodado ביבל, era un reputado hajam o sabio judío ${ }^{37}$. Si bien carecemos de elementos definitivos para afirmar la identidad entre el testigo y el progenitor, tampoco los hay para descartar esa posibilidad, más aun si tenemos en cuenta la presencia documentada en Salamanca

\footnotetext{
${ }^{36}$ Yolanda Moreno Koch, Fontes Iudaeorum Regni Castellae. V. De iure hispanohebraico. Las Taqqanot de Valladolid de 1432. Un estatuto comunal renovador (Salamanca: Universidad Pontificia de Salamanca, 1987) págs. 59 y 61.

${ }^{37}$ Alcalá: Miguel de Eguía, 1526 [pág. 432]. Un estudioso reciente de la figura y la obra del hebraísta recuerda la dificultad de entender el significado del alias o sobrenombre «bibel»; $c f$. Carlos Alonso Fontela, «Anécdotas castellanas en escritura hebraica. Apuntes paremiológicos conservados en las anotaciones hebreas de Alonso de Zamora (Ms. Leiden Or. 645)», Sefarad 71 (2011) págs. 349-368: 368. El mismo Alonso de Zamora actúa años más tarde como perito ante un tribunal inquisitorial en Alcalá de Henares; vid. Carlos Carrete Parrondo, «Tres precisiones de Alonso de Zamora ante el tribunal de la Inquisición», Sefarad 34 (1974) págs. 115-117.
} 
en 1508 de Alonso de Zamora, zapatero, cuando es contratado por la universidad $^{38}$.

Aunque entre los argumentos de los testigos autóctonos de Salamanca se especifica cuál era la costumbre en torno a segundos y terceros matrimonios, el resto aborda la cuestión del régimen matrimonial desde una perspectiva general. La mayoría de ellos coincide en que pese al régimen imperante, eran las cláusulas establecidas entre los cónyuges las que determinaban cómo se iba a desarrollar ese matrimonio.

\subsection{Salamanca}

Atendiendo las respuestas de los testigos oriundos de Salamanca, el régimen de bienes comunes no se seguía entre los judíos de la ciudad. Según el testimonio de Gabriel de Huerta, cuando un judío casaba por segunda o tercera vez y tuviera hijos de los anteriores matrimonios, «fazía carta a la muger», es decir le otorgaba la ketubbá, con el fin de que la unión fuese válida y quedaran establecidas las cantidades aportadas por las partes, así como las condiciones a tener en cuenta durante el matrimonio $^{39}$. Por medio del contrato matrimonial se establecía la entrega de determinados bienes a la mujer, pero con ello también se restringía su acceso al resto del patrimonio del marido. En el siglo XV, el derecho común en la Corona de Castilla prohibía al marido entregar a modo de arras una cantidad superior a la décima parte de sus propiedades ${ }^{40}$. Esta medida preventiva trataba de facilitar la devolución y transmisión de la dote sin que la familia del marido se viera comprometida económicamente. Además, con ello también se impedía que la mujer tuviese derecho sobre el resto de bienes del marido ${ }^{41}$.

\footnotetext{
${ }^{38}$ Carlos Carrete Parrondo, Hebraístas judeoconversos en la Universidad de Salamanca: siglos XV-XVI. Lección inaugural del curso académico, 1983-1984 (Salamanca: Universidad Pontificia de Salamanca, 1983) págs. 16-22.

${ }^{39}$ LaCave, Medieval Ketubot from Sefarad, págs. 133-135.

${ }^{40}$ Siguiendo lo dispuesto en Fuero Real 3.2.1, vid. Partidas 5.4.9 (Sevilla: 1491, con adiciones de Alfonso Díaz de Montalvo).

${ }^{41}$ Cf. Teresa SÁnchez Collada, «La dote matrimonial en el derecho castellano en la Baja Edad Media. Los protocolos notariales del Archivos Histórico Provincial de Cuenca (1504-1507)», Espacio, tiempo y forma. Serie III. Historia Medieval 29 (2016) págs. 699-
} 
Respecto a la transmisión de bienes entre los judíos de Salamanca, el casamentero Álvaro Gómez explicaba que en el régimen matrimonial de bienes propios, la mujer solo tenía derecho a recuperar su dote y a recibir las arras con independencia del resto de bienes que poseyera el marido. Del mismo modo, si durante el matrimonio se ganaba algún tipo de bienes fruto de aquellos que componen la dote y las arras, la mujer recibía la mitad de los mismos.

Poniendo en relación este testimonio con los datos obtenidos a través del estudio de pleitos litigados ante la Audiencia Real con anterioridad a 1492, que tratan de la reclamación de la dote y arras por parte de viudas judías, se puede afirmar que el régimen matrimonial de bienes privativos debió de imperar también entre los judíos asentados en algunas localidades del valle del Duero, puesto que en ninguno de estos casos se reclamaban otros bienes aparte de los del contrato matrimonial (dote y arras) ${ }^{42}$. Este régimen vendría propiciado por la necesidad de salvaguardar el patrimonio personal de los contrayentes, así como asegurar su adecuada transmisión a la familia de origen o a la descendencia. Por este motivo, en la documentación también se observa cierta reticencia por parte de los familiares del marido en el momento de entregar a la mujer las arras si el matrimonio no había concebido descendencia ${ }^{43}$.

\subsection{Zamora}

El testigo Juan de Çamora, el Viejo, muestra conocer bien la situación entre los judíos de Zamora, donde, a fines del siglo XV, los bienes aportados por los cónyuges al matrimonio eran comunes, salvo que se hiciera «atajo» (restricción de bienes), «yguala» (división equitativa de bienes) $\mathrm{o}$ «condición» (cláusula matrimonial, en hebreo tenay) que lo regulase ${ }^{44}$.

\section{4: $723-724$.}

${ }^{42}$ Esta afirmación se fundamenta en la información recogida en mi tesis doctoral en curso, donde se analizan otros casos locales relativos a la transmisión de la dote y las arras.

${ }^{43}$ AGS, RGS, 11-III-1494, fol. 324 (Medina del Campo).

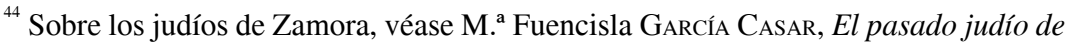
Zamora (Valladolid: Junta de Castilla y León, 1992), que recopila fundamentalmente las fuentes locales disponibles. 
Los términos empleados aparecen de manera recurrente tanto en algunas ketubbot como en ordenanzas, siendo el último de ellos, el usado para la regulación de los acuerdos prematrimoniales ${ }^{45}$. De hecho, el testigo Pedro de Çamora declaraba que cuando su padre falleció, su madre recibió únicamente la dote y las arras, lo que apunta al establecimiento de algún tipo de cláusula prematrimonial que regulaba el régimen de bienes imperante en la aljama de Zamora.

Volviendo a la información proporcionada por Juan de Çamora, la costumbre entre los judíos de Zamora debía ser aplicada a todos los judíos, hombres y mujeres, de la aljama, independientemente de su capacidad económica, es decir, estaba amparada por la fuerza de una ordenanza en vigor ${ }^{46}$. Este dato es relevante porque la comunidad de bienes conllevaba la pérdida de parte del patrimonio de una de las familias en favor del cónyuge superviviente, que tenía derecho a heredar una parte de los bienes gananciales del fallecido/a.

La costumbre vigente en Zamora guarda cierta semejanza con la norma de transmisión de bienes acordada en 1494 y 1496 por los judíos de Castilla exiliados en Fez. En estas ordenanzas también se establece que al fallecer uno de los cónyuges, el viudo/-a tenía derecho a heredar una parte de los bienes matrimoniales (inalienables) y usufructuarios con los descendientes (entre los que se incluyen padre y hermanos varones).

3. Otrosí. Quando la mujer fuere fallecida en vida de su marido e dexare descendencia del dicho su marido que parta con el descendiente mitad por mitad, y también así si eredaren padre o ermanos.

(5.) Si dexare descendencia de ella, que parta la mujer con aquel descendiente todo lo que se fallare en el momento de su fallecimiento mitad por mitad. Y así si sus herederos fueren su padre o sus hermanos se considerarán también ellos como su descendencia ${ }^{47}$.

\footnotetext{
${ }^{45}$ Entre las condiciones más repetidas en las ketubbot conservadas se incluye la prohibición de que el marido pudiera obligar a la mujer a residir en otra localidad, o la obligación de conceder el guet ('carta de divorcio') a la mujer en caso de que este estuviera expuesto a una situación grave.

${ }^{46}$ Así se establece en una tacaná de Tudela (1287): «que esta ley sea igual para pobres que para ricos»; LACAVE, Los judíos del Reino de Navarra, pág. 36 (doc. 1).

${ }^{47}$ Cláusulas 3 y $5 ; c f$. LAREDO, «Las taqanot de los expulsados de Castilla en Marruecos
} 
Asimismo, el testigo Juan de Çamora informa de que si un matrimonio no hubiera concebido descendencia, el marido debía comprometerse a mantener el «casamiento en pie», es decir a no divorciarse de su mujer. Sin embargo, en el caso de que en Zamora uno de los cónyuges muriera sin descendientes, se le debía devolver la dote por completo a su propietaria o a sus herederos, en su caso, y la alianza establecida entre esas dos familias se disiparía. De igual modo se descarta la opción al levirato. Este dato señala que el marido no tenía derecho a heredar de su esposa en esta situación, pero ¿podía una mujer sin hijos recibir las arras aportadas por su marido al casamiento?

A diferencia de las interpretaciones de los testigos procedentes de Zamora, en las ordenanzas de Fez se estipula que en un caso como este, el viudo/a tiene derecho a heredar dos tercios de los bienes del fallecido/a en perjuicio de los herederos, imperando por completo el régimen de bienes comunes:

2. Otrosí. Quando la mujer fuere fallecida en vida de su marido e non dexare descendencia, que tome el marido dos terçios de todos los bienes que se falleren en el momento de su fallecimiento, y sus herederos ayan el terçio fincable.

5. Otrosí. Quando fallesiere el marido en vida de su mujer e non dexare descendencia de ella que tome la mujer de todo lo que se fallare dos tersios en el momento de su fallecimiento y el tercio restante para sus herederos hasta tercer grado ${ }^{48}$.

\section{CONSIDERACIONES FinALES}

El interrogatorio del pleito presentado por la parte de la conversa Isabel de Cartagena nos permite ahondar en un aspecto fundamental de las costumbres y normas de transmisión de la herencia dentro del matrimonio judío y de las particularidades de los regímenes de bienes a partir del caso de Salamanca y Zamora. Si bien las declaraciones de los testigos conver-

\footnotetext{
y su régimen matrimonial y sucesorial», pág. 272.

${ }^{48}$ Cláusulas 2 y $5 ; c f$. LAREDO, «Las taqanot de los expulsados de Castilla en Marruecos y su régimen matrimonial y sucesorial», pág. 272.
} 
sos han de ser entendidas como interpretaciones sobre la norma, el tribunal real hubiera tenido difícil averiguar esta cuestión sin su testimonio.

A través del análisis precedente podemos apuntar a una diversidad de costumbres legales relativas al matrimonio y en vigor entre los judíos de Castilla con anterioridad a 1492 en lo que se refiere al régimen matrimonial establecido por las aljamas. Asimismo, dicha diversidad se agudiza por las disposiciones de carácter económico acordadas por las familias de los contrayentes. El régimen matrimonial condicionaba la transmisión de sus bienes; en el caso de un régimen de bienes comunes, se posibilitaba a la mujer heredar de su marido. En el caso de segundos y terceros matrimonios, la cantidad a recibir por la mujer no incluía los bienes recibidos por el marido de un matrimonio anterior, ya que pertenecían a los descendientes o herederos del mismo.

A modo de epílogo es preciso recordar aquí el carácter complementario de estas fuentes documentales por su importancia para la reconstrucción de aspectos internos de las sociedades judías peninsulares y de sus mecanismos sociales de funcionamiento. En el caso de este proceso conservado de manera fragmentaria, su lectura deja abiertos bastantes interrogantes, tanto en relación a la resolución final, como a las complejas y variadas identidades de los individuos envueltos. Sin embargo, es una muestra de que si las prácticas sociales vinculadas a los judíos y al judaísmo son prohibidas a partir de 1492 en la Corona de Castilla, las huellas que aquellas dejan no se desvanecen de la noche a la mañana. 
APÉNDICE DOCUMENTAL

1500 , julio 28. Salamanca

Interrogatorio del pleito entre Isabel de Cartagena, mujer de Fernando de la Peña, y el convento de Santa María de la Anunciación de Salamanca sobre la herencia y bienes de Abrahán de la Fuente, difunto. Dentro del texto se inserta la carta de receptoría de testigos emitida por los Reyes ${ }^{49}$.

ARChV, Pleitos civiles, Zarandona y Walls (Olvidados), caja 1365-2

[...] E después d'esto en la dicha çibdad de Salamanca a treze días del dicho mes de jullio e año de mill e quinientos años sobredicho, ante el dicho bachiller e alcalde Rodrigo Guyllén e en presençia de nos, los dichos Juan Sanches Montesyno e Rodrigo Ruano, escriuanos públicos, e de los testigos ynfraescriptos paresçió ay presente el dicho Ferrando de la Peña en el dicho nonbre de la dicha Ysabel de Cartagena, su muger, e presentó vn escripto de interrogatorio, su thenor del qual es este que se sygue:

E las preguntas que han de ser fechas a los testigos presentados por parte de Ysabel de Cartagena en el pleyto e cavsa que con ella ha e trata el monesterio, abadesa, monjas e convento de Santa María de la Anunçiación desta çibdad de Salamanca, para en prueva de la contradiçión e tachas de los testigos presentados por parte del dicho monesterio:

I. Sean preguntados sy conosçieron a Abrahan de la Fuente e a Hazibuena, su terçera muger, e sy conosçen a Ysabel de Cartagena, mi parte.

II. Yten. Sean preguntados sy saben, tuvieron o oyeron desyr que sy costunbre alguna entre los judíos auía que quando alguno se casaua con segunda o terçera muger, que todos los bienes heran comunes que cada vno dellos trayan al tienpo que se casauan. Questa costunbre non se vsaría, nin guardaría en todos los logares, especialmente non se vsaua, nin guardaua en la çibdad de Salamanca, nin entre los judíos, nin [al]jama della al tienpo quel dicho Abrahán de la Fuente s[e] casó con la dicha Azibuena, e que sy se vsara e guardara entre los judíos e aljama della al tienpo quel dicho Abrahán de la Fuente se casó con la dicha Azibuena, estos testigos lo supieran. Mas porque non avían la tal costunbre, non la

\footnotetext{
${ }^{49}$ AGS, RGS, 1-VII-1500, fol. 48 (Valladolid).
} 
supieron e que en cada logar avía diversydad de su costunbre, e çerca desto digan e declaren lo que saben desta pregunta.

III. Yten sean preguntados sy saben, etc. que Françisco de León e Juan de Çamora, el viejo, e Juan de Salamanca e Françisco de Piedrahita e Françisco Palomeque, que sastres que son todos, veçinos desta çibdad de Salamanca, al tienpo e a la sazón que se tornaron christianos, que fue al tienpo del destierro de los judíos, nin antes quando se casó el dicho Abrahán de la Fuente con la dicha Hazibuena, no heran veçinos nin moradores desta dicha çibdad de Salamanca, nin naturales della, e que sy lo fueran estos dichos testigos lo supieran, segund la mucha conversaçión e trato que entre los judíos e aljama desta çibdad tenían. E que sy la dicha costunbre avía, sería en otros logares donde fuesen naturales e non en esta çibdad de Salamanca. E digan e declaren los dichos testigos lo que saben desta pregunta. [...].

E lo que los dichos testigos presentados por el dicho Ferrando de la Peña en nombre de la dicha Ysabel de Cartagena, su muger, dixeron e depusyeron syendo preguntados por el dicho interrogatorio, cada vno por sy secreta e apartadamente so cargo del juramento por ellos fecho, es lo syguiente:

[1] El dicho Juan de Çamora, el Viejo, sastre, veçino de la dicha çibdad, testigo susodicho, jurado e preguntado por el dicho ynterrogatorio.

Syendo preguntado por los artyculos contenidos en la dicha carta, dixo que ha sesenta años e algo más, e que non querría que diesen sentençia saluo por la parte que touiese más justiçia. E que los otros artyculos e calidades en la dicha carta contenidos non le enpeçan, nin concurren en este testigo.

A la primera pregunta dixo que conosçe a la dicha Ysabel de Cartagena de vista e fabla, e que a los otros contenidos en la pregunta, que los non conosçe.

A la segunda pregunta dixo queste testigo non es natural desta çibdad, nin sabe la costunbre que en ella se tenía entre los judíos, pero que en Çamora, donde este testigo es natural e se crió e biuió fasta que se fueron los judíos, tenían por costunbre que quando algund judío se casaua, que los bienes que trayan el vno a la conpañía del otro heran comunes, saluo sy fazían atajo e yguala e condiçión. Esto se entendía entre los ricos e avn entre los pobres. Que sy entendían de non aver fijos, el marido se 
obligava a tener el casamiento en pie e boluerlo a los herederos della o a ella syendo biua.

A la terçera pregunta dixo que sabe e es notorio que los contenidos en la pregunta non son naturales desta çibdad, porqu'este testigo es vno d'ellos, qu'es de Çamora, e Françisco de León es de Santhagund, e Palomeque es de Almaçán, e Françisco de Piedrahita es de Piedrahita, e que al tienpo e sazón qu'el dicho Abrahán se casó con la dicha Azibuena, nin quando murió non estauan en esta çibdad de Salamanca. E que quanto a la costunbre dixo que desya lo que dicho auía en la pregunta antes d'esta.

Preguntado por las otras preguntas al caso e fecho perteneçientes dixo que desya lo que dicho auía e que en ello se afirmava e afirmó, e qu'esta es la verdad e lo que d'este fecho sabe e non más, so cargo del juramento que fizo.

[2] El dicho Pedro de Çamora, testigo susodicho, jurado e preguntado. Syendo preguntado por los artyculos de la dicha carta dixo que avría çincuenta e çinco años poco más o menos e que non tiene parentesco alguno con ninguna de las partes, e que ninguno de los artyculos e calidades en la dicha carta contenidos non concurre en este testigo, nin le enpeçan.

A la primera pregunta dixo que conosçe a la dicha Ysabel de Cartagena de vista e fabla, e que a los otros contenidos en la dicha pregunta, que los non conosçió, porqu'este testigo non es natural d'esta çibdad, antes es de Çamora.

A la segunda pregunta dixo que la costunbre d'esta çibdad que se tenía çerca de lo contenido en la dicha pregunta que lo non sabe, porqu'este testigo non hera de la çibdad, que hera de la çibdad de Çamora segund dicho tiene. E que en Çamora la costunbre hera que davan arras a las mugeres al tienpo que se casauan segund la condiçión que ponían, porque su madre d'este testigo hera de Benavente e se casó en Çamora, e al tienpo que su marido murió le dieron su dote y las arras que le mandó.

A la terçera pregunta dixo que desya lo que dicho avía en la pregunta de suso e que a los contenidos en la dicha pregunta non los conosçió antes más de quanto agora conosçe al Juan de Çamora, el Viejo, e al Palomeque. Qu'esta es la verdad e lo que d'este fecho sabe e non más, so cargo del juramento que fizo.

[3] El dicho Gabriel de Huerta, sastre, testigo susodicho, jurado e preguntado, syendo preguntado por los artyculos en la dicha carta conteni- 
dos, dixo que avrá treynta o treynta e dos años, e que non es pariente de ninguna de las partes e que den sentençia por quien touiese justiçia. E que ninguno de los otros artyculos e calidades en la dicha carta contenidos non concurren en este testigo, nin le enpeçen.

A la primera pregunta dixo que conosçió a Abrahán de la Fuente e conosçe a Ysabel de Cartagena, su muger, de vista e fabla e conversaçión, e que a la dicha Azibuena que non la conosçió.

A la segunda pregunta dixo que oyó desir a algunas personas que non se acuerda, que quando quiera que algund judío casaua segunda o terçera vez en esta çibdad e auía fijos de otra muger que fazía carta a la muger que tomava de aquello, porque heran conçertados al tienpo que se contratava el casamiento.

A la terçera pregunta dixo que sabe que los contenidos en la dicha pregunta non heran d'esta çibdad, nin moraron en ella mientras avía judíos, porque sy moraran este testigo los conosçiera, porque conosçió a todos los judíos d'esta çibdad e aljama d'ella, e que los contenidos en la dicha pregunta biuen aquí en esta çibdad desde que los judíos se fueron destos reygnos e se boluieron christianos, exçebto que Françisco de Piedrahita qu'este testigo lo vido quando mu[cha]cho en esta çibdad, e que non sabe dónde es natural, e que los demás contenidos en la dicha pregunta dixo que desya lo que dicho auía. E qu'esta es la verdad e lo que d'este fecho sabe e non más so cargo del juramento que fizo.

[4] El dicho Françisco Palomeque, testigo sobredicho, jurado e preguntado por los artyculos en la dicha carta de sus Altezas contenidos, dixo que avrá veynte e ocho años poco más o menos, e que non es pariente de ninguna de las partes, e que vença el que touiere justiçia, e que los otros artyculos en la dicha carta contenidos nin alguno d'ellos non están nin concurren en este testigo.

A la primera pregunta del dicho ynterrogatorio dixo que conosçe a la dicha Ysabel de Cartagena de vista e fabla e trato e conversaçión, e que a los otros contenidos en la dicha pregunta, que los non conosçió porqu'este testigo non es d'esta çibdad.

A la segunda pregunta dixo que en algunos logares auían sus costunbres segund las condiçiones que ponían al tienpo que se casaua el hombre con la muger, avnque fuesen él biudo o ella e touiese el vno fijos o el otro fijos. Pero qu'el derecho e la ley establesçida entr'ellos hera en el 
tienpo de los judíos lo que tiene dicho en su dicho que dixo e depuso ante Françisco Mandaleno, escriuano público del número d'esta çibdad de Salamanca. E que la costunbre o condiçiones que los judíos tenían en esta çibdad este testigo non lo sabe, porque non hera d'esta çibdad.

A la terçera pregunta dixo que ha oydo desir por notorio que los contenidos en la dicha pregunta non heran d'esta çibdad, e que en lo de la costunbre que se refiere a lo dicho en la pregunta antes d'esta. E qu'esta es la verdad e lo que del dicho negoçio sabe e non más, so cargo del juramento que fizo.

[5] El dicho Aluar Gómez, testigo susodicho, jurado e preguntado por los artyculos contenidos en la dicha carta dixo qu'este testigo avrá çerca de çincuenta e çinco años, poco más o menos, e que non es pariente de ninguna de las partes e que vença el que touiere justiçia, e que non concurren nin están nin enpeçan a este testigo ninguno de los artyculos e calidades de la dicha carta.

A la primera pregunta dixo que conosçió e conosçe a todos los en la dicha pregunta contenidos de vista e trato e conversaçión que con ellos e con cada vno d'ellos tovo.

A la segunda pregunta dixo que sabe que en cada logar avía su manera de costunbre çerca de lo contenido en esta pregunta, e que en esta çibdad tenían costunbre que al tienpo que algund judío se casaua segunda o terçera vez que los bienes que trayan él al poder de la tal muger, la muger non tenía parte en ellos más de quanto le mandava el varón en arras, e sy algo se ganava durante el matrimonio que llevava su parte la muger.

A la terçera pregunta dixo que sabe que los contenidos en la dicha pregunta non heran d'esta çibdad e que lo sabe porqu'este testigo es natural d'esta çibdad, e que a lo de la costunbre que dezía lo que dicho auía en la pregunta de suso. E qu'esta es la verdad e lo que d'este fecho sabe e non más, so cargo del jura[mento] que fizo.

[6] El dicho Françisco de Piedrahita, testigo susodicho, jurado e preguntado, syendo primeramente preguntado por los artyculos de la dicha carta dixo que non es pariente de ninguna de las partes e que non viene sobornado, nin dadiuado, e que algunas vezes le ha pasado por el pensamiento de querer que vençiese el monesterio. 
A la primera pregunta dixo que conosçe a la dicha Ysabel de Cartagena de vista e fabla, e que a los otros contenidos en la dicha pregunta que non los conosçió.

A la segunda pregunta dixo que non se le acuerda cosa alguna de las costunbres que tenían los judíos en esta çiudad, nin avn las que tenían en otras partes, porqu'este testigo es moço e cree que la costunbre sería segund las condiçiones que ponían al tienpo que casauan.

A la terçera pregunta dixo que sabe que los contenidos en esta pregunta non son d'esta çibdad, porqu'este testigo, antes que se fuesen los judíos, estaua en esta çibdad e conosçió bien a los judíos qu'estauan en ella, pero que tampoco este dicho testigo es natural d'ella, puesto que antes que los judíos se fuesen destos reygnos estaría este testigo en esta dicha çibdad çerca de tres años, e que en lo de la costunbre dezían lo que dicho auía. E qu'esta hera la verdad e lo que del dicho negoçio sabía, so cargo del juramento que auía fecho.

Recibido: 23/11/2017

Aceptado: 15/03/2018 